\title{
IMPACT OF MIDDLEMEN ON VEGETABLE MARKETING CHANNELS IN SRI LANKA
}

Sandika AL

Department of Agricultural Economics, Faculty of Agriculture, University of Ruhuna, Mapalana, Kambu-

rupitiya, Sri Lanka

Accepted: 11 November 2011

\begin{abstract}
Vegetable are produced on a year round basis and a large number of farmers are involved in the process of production. However, many people criticize the vegetable marketing system due to fluctuating prices. In this background, this paper attempts to identify the long-term behaviour of Market Margin (MM) of middlemen on vegetable marketing channels in Sri Lanka. This study was mainly done by using secondary data. Nominal market price, producers price and market margin (MM) of beans, carrots, beets, pumpkin and brinjals have increased in a similar percentage in parallel to the prevailing rapid inflation within the last two decades. Therefore, it is clear that the prices of the vegetables have increased due to the high rate of inflation in the country. The MM for the all the vegetables was generally less than $50 \%$. Average MM of selected vegetables like bean, carrot, beet, pumpkin and brinjals were $42 \%, 44 \%, 44 \%, 49 \%$ and $43.5 \%$, respectively. It was also observed that usually when the Retail Price (RP) and Producer Prices (PP) increase the MM decrease and vice versa. It is clear that when the RP and PP are high the middlemen try to control the market prices by reducing their MM. It may help to protect the consumers directly because RP and PP normally increase due to low supply of the production of vegetable and/or high demand for it. When the prices are low they try to get more benefits by increasing their MM as a rational entrepreneur.
\end{abstract}

Key words: Retail Price, Producer Price, Market Margin, Marketing Channel

\section{INTRODUCTION}

Sri Lanka is still considered as an agricultural country because majority of rural people is still engaged in agricultural sector which is their main livelihood. In the agricultural sector in Sri Lanka the vegetable sub-sector is the second most important sub-sector after rice. Vegetable are produced on a year round basis and a large number of farmers are involved in the production process (Vidanapathirana 2008). Both low country and up country vegetable production have significantly increased during the last few years because of the high promotional campaigns conducted by the Department of Agriculture (DOA) and other allied departments under the program named 'let us cultivate and uplift the nation', (Central Bank, 2008) and establishment of one million Domestic Economic Units known as the 'Divi Neguma, program (Department of Agriculture 2011). A major share of the produced vegetables is consumed locally and the share of exports amount is less than one percent.

Verma et al. 2002, indicated that the marketing of vegetables, unlike in the case of cereals, is

*Corresponding author: sandika@agecon.ruh.ac.lk more complex because of its special characteristics like highly perishable nature, seasonality, bulkiness etc, Also it needs special care and immediate disposable. In this situation, it is difficult to recognize the efficiency of marketing vegetables because both parties such as producers and consumers are exploited by the intermediaries. Therefore, building up of a new market complex named 'Economic Center' with all the modern amenities is supposed to influence the market structure and the pricing mechanism. This will also benefit the growers to obtain higher prices by increasing the efficiency of market and reducing various losses.

Vegetable marketing in Sri Lanka is generally in the hands of the private sector, (Vidanapathirana 2008). The marketing operation has a crucial role in deciding the profit of the farmer and the level of availability to consumers on the other hand. High marketing costs and market margin are major issues in the present scenario. Marketing channel is a chain of middlemen who are involved in the process of selling different vegetables at different stages. Existing marketing channel of vegetables in Sri Lanka is explained by the figure 1 . 


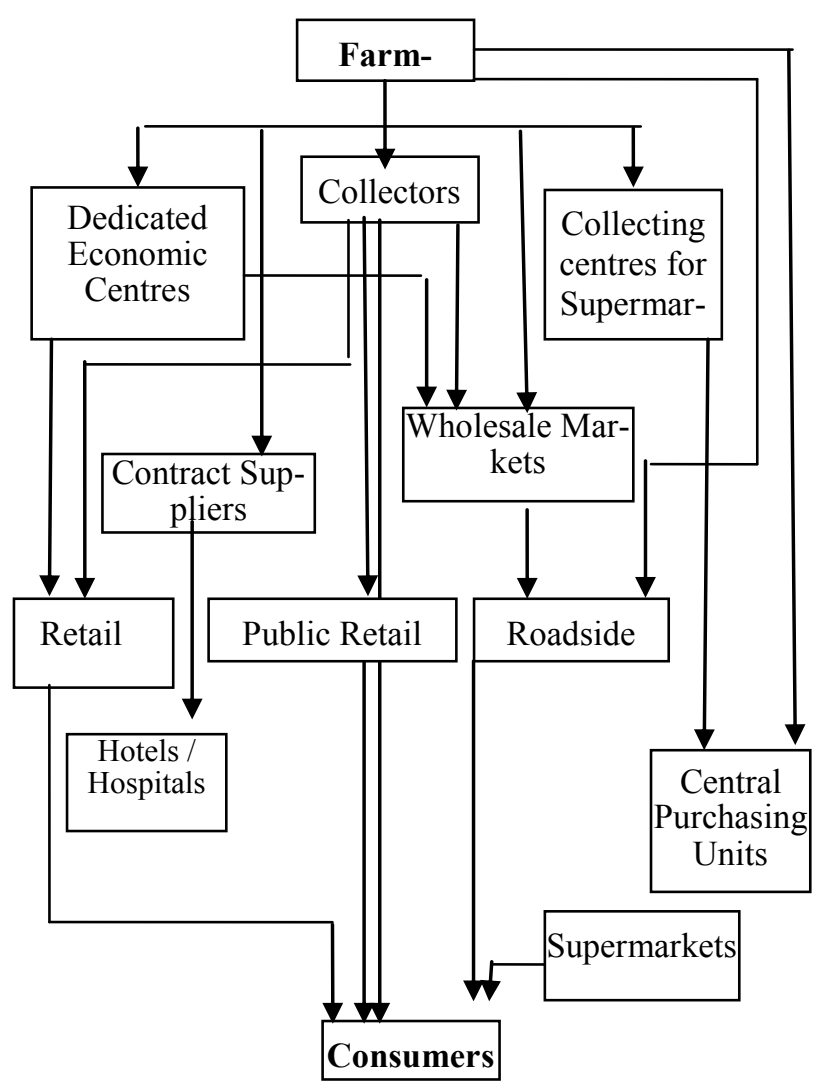

Figure 1 Vegetable distribution system in Sri Lanka (Source: Vidanapathirana 2008)

Prices are the result of the functioning of the market and are determined by supply and demand which, in turn, is influenced by the costs of production, the costs of marketing and consumer preferences, among other things. Generally, the price fluctuation of vegetables is higher than other agricultural products, (Bambang 2007). Middlemen are the key person in the Sri Lankan vegetable marketing channel that brings the farm product to the ultimate consumer. In this regard, they have to bear a high cost and risk. Generally, purchasing, transporting, loading and unloading, grading, storage, wastage and price risk are the major cost components. Additionally, they expect a profit in their business. Rupasena et al. 2008 explain that the total margin includes the cost involved in moving the product from the point of production to the point of consumption, i.e. the cost of performing the various marketing functions and the profits of the various market functionaries involved in the moving the product from the initial point of production to the ultimate consumer. Ultimate price will be increased when the numbers of points in the market channel are increasing. In this situation many communities such as politicians, journal- ists, consumers and farmers blame that the farmers' and consumers' rights are exploited by the middlemen. Even though the middlemen are criticized by the others, middlemen play key roles such as collecting, grading, storage, distributing and selling in the vegetable marketing channels. Many researchers have studied the impact and market margin of the middlemen in the short term period. In this background, this paper attempts to identify the long -term behaviour of Market Margin (MM) of middlemen on vegetable marketing channels in Sri Lanka.

\section{METHODOLOGY}

This study was mainly done by using secondary data which was collected from secondary sources such as central bank report, retail prices reports published by the Department of Census and Statistics and other allied departments. Availability of the data, Nominal Market Price (NMP) and Producer Price (PP) of bean, carrot, beet, pumpkin and brinjals were collected to measure the middlemen impact on vegetable marketing channel in Sri Lanka. Considered time period was seventeen years (from 1991 to 2008).

Middlemen impact on vegetable marketing channel was measured by considering Marketing Margin (MM) of the middlemen. $\mathrm{MM}$ is the difference between the price paid by the ultimate consumer and the price received by the producer or farmer. The MM represents all assembling, transporting, other retailing charges and profit margin added to the farm products. i.e. the cost of providing a range of marketing services, (Khan at el. 2005). MM of middlemen was measured by adopting to following equation (i):

$$
\begin{array}{ll}
\mathrm{MM}=\frac{\mathrm{RP}-\mathrm{PP}}{\mathrm{RP}} & \mathrm{PP}-\text { Producer Price } \\
\mathrm{RP}-\text { Retail Price }
\end{array}
$$

Time Series (TS) plots were used to identify the major price behaviour patterns against the time factor, (Madridakis et al. 1983). Both Nominal Market Prices (NMP) and Real Market Price (RMP) were analyzed with the time. Colombo Consumer Price Index (CCPI) (1990 $=100$ ) was used to calculate the RMP, (Hadley 1969). The formula (ii) was applied to calculate the RMP was: 
$\mathrm{RMP}=(\mathrm{NMP} \times 100) / \mathrm{CCPI}$

Price behaviour of selected vegetables was tested by using Compound Growth Rate (CGR) $\left(\mathrm{Y}=\mathrm{ab}^{\mathrm{X}}\right)$ models with the time factor. CGR was calculated by employing the equation (iii).

$$
\mathrm{CGR}=(\mathrm{b}-1) 100
$$

The goodness of fit of model was tested by using coefficients of determination $\left(\mathrm{r}^{2}\right)$, (Majumdar, 2002). Coefficient of determination was measured by applying the formula (iv):

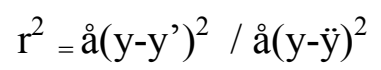

The results were elaborated by using tables and charts.

\section{RESULTS AND DISCUSSION}

RP of the selected vegetables have drastically increased during the last two decades, (Fig. A). With respect to the nominal market prices of bean, carrot, beet, pumpkin and brinjals have increased by $398 \%, 346 \%, 338 \%, 348 \%$ and $456 \%$ respectively in the considered time period. Further, a price of bean has annually increased by $10 \%$ while it was $9.2 \%, 8.0 \%$, $9.3 \%$ and $10 \%$ for carrot, beet, pumpkin and brinjals respectively. When considering the producer prices or farm gate prices, figure B clearly illustrates that the PP have also increased significantly. It is important to highlight here that the PP have also increased in the same percentage. The PP of bean, carrot, beet, pumpkin and brinjals have also increased by $389 \%, 418 \%, 329 \%, 288 \%$ and $460 \%$, respectively. Further, PP of the selected vegetables has also increased in a similar rate annually: bean prices by $10 \%$, carrot prices by $10 \%$, and beet prices by $8 \%$, pumpkin by $8.6 \%$, and brinjals by $10 \%$.

The other important key point is how margin of middlemen has increased with the time. With respect, the MM of middlemen regarding bean, carrot, beet, pumpkin and brinjals have increased by $411 \%, 275 \%, 351 \%, 422 \%$ and $450 \%$ respectively during the considered time period (Fig. C). Annual growth of the MM of the middlemen has recorded $9.4 \%$ for bean, 8 $\%$ for carrot, $8 \%$ for beet, $10 \%$ for pumpkin and $10 \%$ for brinjals (Table 1 and Table 2).
Table 1: Growth of retail price, producer price and market margin

\begin{tabular}{lllllll}
\hline Vegetables Retail Price & \multicolumn{4}{c}{ Producer Price Market Margin } \\
\cline { 2 - 7 } & \multicolumn{2}{l}{$\begin{array}{l}\text { Overall Growth Overall Growth Overall Growth } \\
\text { incre- }\end{array}$} & /year & incre- & / year \\
ment & & ment & & incre- & /year \\
& ment & \\
\hline Bean & $398 \%$ & $10 \%$ & $389 \%$ & $10 \%$ & $411 \%$ & $9.4 \%$ \\
Carrot & $346 \%$ & $9.2 \%$ & $418 \%$ & $10 \%$ & $275 \%$ & $8 \%$ \\
Beet & $338 \%$ & $8 \%$ & $329 \%$ & $8 \%$ & $351 \%$ & $8 \%$ \\
Pumpkin & $348 \%$ & $9.3 \%$ & $288 \%$ & $8.6 \%$ & $422 \%$ & $10 \%$ \\
Brinjals & $456 \%$ & $10 \%$ & $460 \%$ & $10 \%$ & $450 \%$ & $10 \%$ \\
\hline
\end{tabular}

Other important silent feature was the growth in the inflation during the considered time period. Close look at the Figure D clearly illustrates that the inflation has increased by $437 \%$ and it is an increase of $10 \%$ per annum $(\mathrm{b}=$ $\left.1.104, r^{2}=99.1 \%\right)$. On this background, it is clear that RP of the vegetables has increased due to the growth of the inflation in the country. With the inflation rate, all parties of the market chain have increased their portion to meet the sufficient income to fulfill their need.

An attempt was made to identify how real prices have behaved during last two decades. Figures $E, F$ and $G$ show the real prices of the vegetables during the selected time period. The close observation of the figure $\mathrm{E}$ further revealed that the real RP has not increased significantly with the time. Further, real PP also has not significantly increased.

Other important point was $\mathrm{MM}$ of the middlemen in term of real prices also has not increased. These finding supported the result of the earlier analysis. A close look at figure $G$ illustrates that the real $\mathrm{MM}$ of the middlemen show decreasing trend with the time.

Table 3 and figure $\mathrm{H}$ exhibit the $\mathrm{MM}$ in a percentage wise and clearly explain that the MM for all the vegetables is generally less than 50 $\%$ of the consumers price. When considered the $\mathrm{MM}$ of bean, it has generally varied from $36 \%$ to $48 \%$ amount and average of $42 \%$. MM of carrot was little higher than bean and varied from $37 \%$ to $51 \%$ with an average value of $44 \%$. Range of MM of beets' was $36 \%$ to $55 \%$ and average was of $44 \%$. Highest MM was recorded for pumpkin. Average value was 49\% with a $44 \%$ to $53 \%$ range. MM of brinjals' was also relatively high. Average value was $43.5 \%$ and the range has recorded as $40 \%$ to $46 \%$. Vidanapathirana (2008) has obtained the similar results from his study. He pointed out that 
Table 2: CGR and $\mathbf{r}^{2}$ for retail price, producer price and market margin

Vegetables Retail Price Producer Price Market Margin \begin{tabular}{llllll}
\hline $\mathrm{b}$ & $\mathrm{R}^{2}$ & $\mathrm{~b}$ & $\mathrm{R}^{2}$ & $\mathrm{~b}$ & $\mathrm{R}^{2}$
\end{tabular}

\begin{tabular}{|c|c|c|}
\hline$\overline{\text { Bean }}$ & $1.09999 .0 \% 1.10098 .6 \%$ & $1.09493 .6 \%$ \\
\hline Carrot & $1.09297 .6 \% 1.10098 .2 \%$ & $1.07991 .6 \%$ \\
\hline Beet & $1.08093 .5 \% 1$ & 1.082 \\
\hline Pumpkin & $1.09396 .0 \% \quad 1.08695 .6 \%$ & $5.4 \%$ \\
\hline Brinjals & $1.10098 .2 \% 1.09997 .1 \%$ & $1.10296 .5 \%$ \\
\hline
\end{tabular}
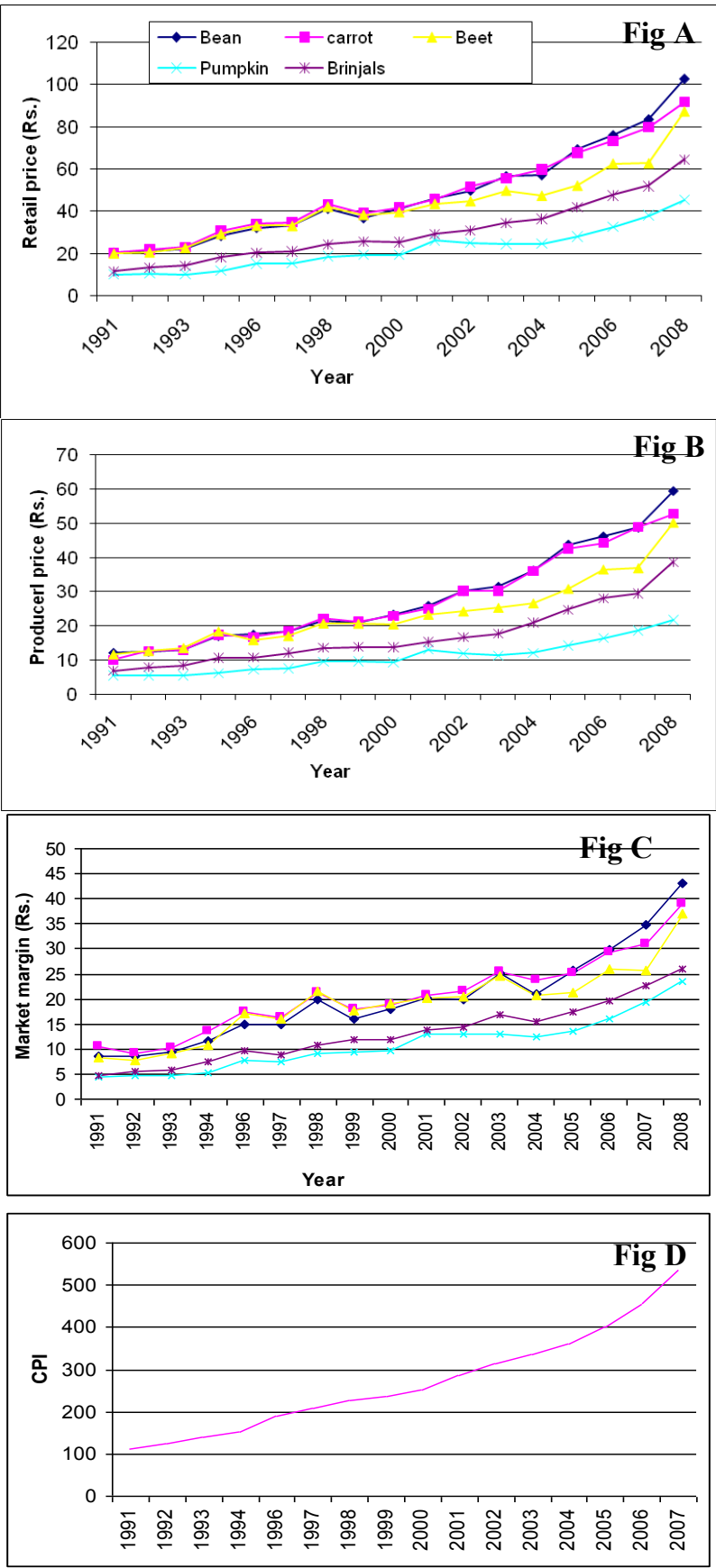

Figure A: Retail prices of selected vegetables, Figure B: Producers' prices of selected vegetables, Figure C: MM of selected vegetables, Figure D: CPI growth during the last two decades
MM of beans, carrot, leeks, beetroot, tomato and capsicum was less than $55 \%$ in the year 2007. Therefore, the results of this study are supported by the result of the Vidanapathirana's study.

It was also observed that usually when the market prices and producer's prices are high, the $\mathrm{MM}$ is low and vice versa. The close observation of the figure $\mathrm{A}, \mathrm{B}$ and $\mathrm{H}$ further revealed that the highest RP and PP with lowest MM has recorded for bean and carrot. Further, lowest RP and PP and highest MM has recorded for pumpkin. It is clear that when the RP and PP prices are high middlemen try to control the market prices by reducing their MM. It may directly help to protect the consumer because RP and PP normally increase due to low supply of the production and/or high demand. When the prices are low he tries to get more benefits by increasing his MM. On this background, middlemen act as the rational entrepreneur. Vidanapathirana (2008) has found the similar finding for the short period of time. According to him MM vary according to the time of the year, depending upon the prices of vegetables and when the prices are high the MM are low. Moreover, he pointed out that those middlemen help to reduce the extent of seasonality in vegetable prices.

\section{CONCLUSION}

Retail price of bean, carrot, beet, pumpkin and brinjals has annually increased by $10 \%, 9.2 \%$, $8.0 \%, 9.3 \%$ and $10 \%$, respectively. Further, produce price of the selected vegetables also has increased in similar rates annually by $10 \%$ (bean), by $10 \%$ (carrot), by $8 \%$ (beet), by $8.6 \%$ (pumpkin), and by $10 \%$ (brinjals). With respect to the market margin of middlemen regarding bean, carrot, beet, pumpkin and brinjals have also increased almost in a similar rate. Annual growth of the MM has recorded 9.4\% for bean, $8 \%$ for carrot, $8 \%$ for beet, $10 \%$ for pumpkin and $10 \%$ for brinjals. Other important silent feature was increment of the inflation at the respected time period. It has also increased by $10 \%$ annually. On this background, it is concluded that RP of the vegetable has increased due to increment of the inflation in the country. With the inflation rate all parties of the market chain have increased their portion to meet the sufficient income to fulfill their need. 


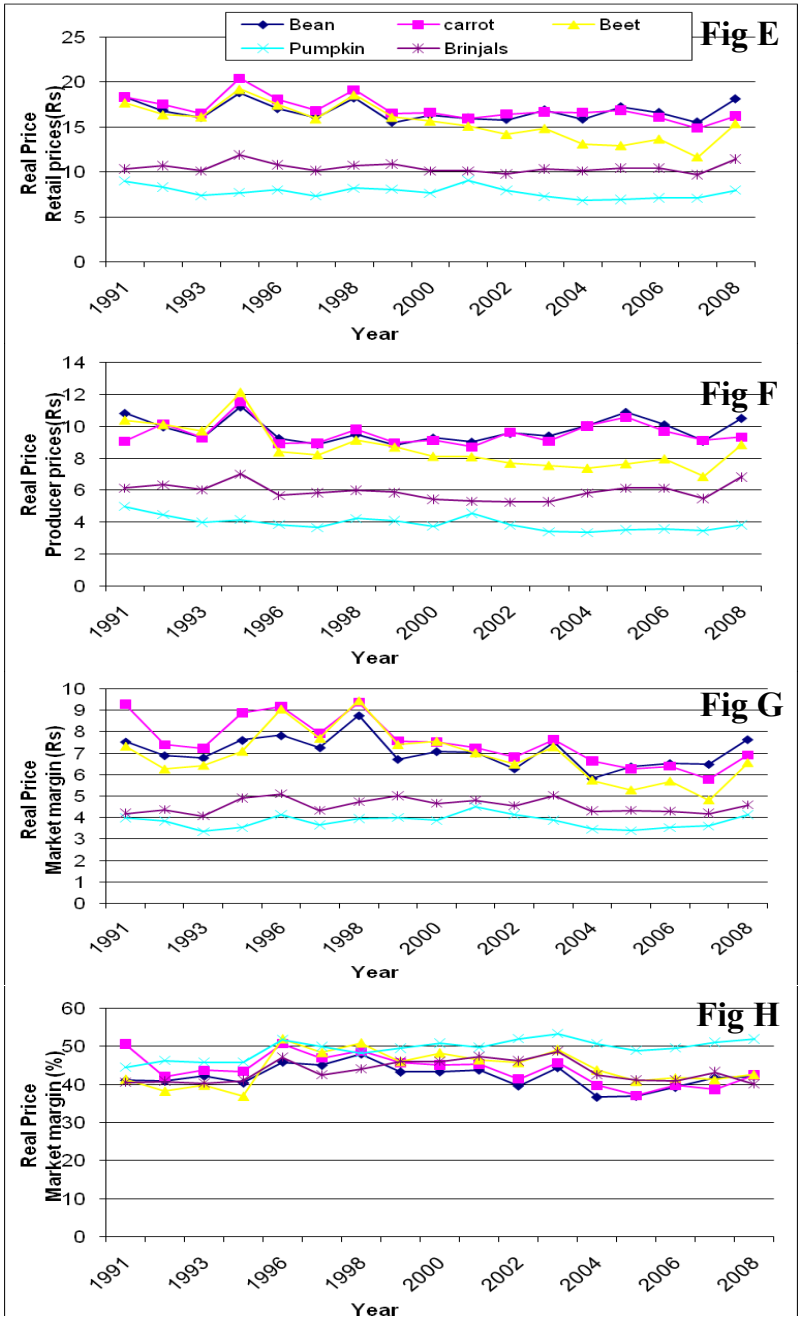

Figure E: Retail prices of selected vegetables, Figure F: Producers' prices of selected vegetables, Figure G: MM of selected vegetables, Figure H: MM (percentage) of selected vegetables during the last two decades

Table 3: Market Margin of the middlemen as a percentage of retail price

\begin{tabular}{lclllc}
\hline Year & Bean & Carrot & Beet & \multicolumn{2}{c}{ Pumpkin Brinjals } \\
\hline 1991 & 41.04 & 50.58 & 41.35 & 44.54 & 40.57 \\
1992 & 40.86 & 42.13 & 38.22 & 46.30 & 40.85 \\
1993 & 42.20 & 43.77 & 39.80 & 45.81 & 40.28 \\
1994 & 40.38 & 43.45 & 36.87 & 45.88 & 41.13 \\
1996 & 45.86 & 50.69 & 51.94 & 51.82 & 47.28 \\
1997 & 45.03 & 46.96 & 48.36 & 49.97 & 42.48 \\
1998 & 48.02 & 48.83 & 50.87 & 48.38 & 44.05 \\
1999 & 43.25 & 45.75 & 45.99 & 49.50 & 46.05 \\
2000 & 43.32 & 45.17 & 48.24 & 50.81 & 46.16 \\
2001 & 43.78 & 45.40 & 46.44 & 49.73 & 47.44 \\
2002 & 39.61 & 41.48 & 45.76 & 52.00 & 46.25 \\
2003 & 44.42 & 45.74 & 49.17 & 53.33 & 48.74 \\
2004 & 36.64 & 39.80 & 43.76 & 50.71 & 42.51 \\
2005 & 36.89 & 37.20 & 40.81 & 48.96 & 41.28 \\
2006 & 39.23 & 39.75 & 41.67 & 49.62 & 41.10 \\
2007 & 41.67 & 38.79 & 41.23 & 51.07 & 43.32 \\
2008 & 42.10 & 42.55 & 42.57 & 51.91 & 40.14 \\
Mean CV & 7.2 & 9.0 & 10.1 & 5.1 & 6.7 \\
\hline
\end{tabular}

The MM for all the vegetables was generally less than 50\%. Average MM of selected vegetables bean, carrot, beet, pumpkin and brinjals were $42 \%, 44 \%, 44 \%, 49 \%$ and $43.5 \%$, respectively. It was also observed that usually when the market prices and producer's prices are high, the MM is low and vice versa. It is clear that when the RP and PP prices are high middlemen try to control the market prices by reducing their MM. Therefore, it helps to protect the consumer because RP and PP normally increase due to low supply of the production and/ or high demand. When the prices are low he tries to get more benefits by increasing his MM. On this background, it is unfair to criticize that the middlemen are exploiting the consumers and producers because they are playing major role in the domestic vegetable marketing channel.

\section{REFERENCES}

Bambang I 2007 "Price Fluctuation, Price Transmission and Marketing Margin of Vegetables and Fruits", Agricultural Policy Analysis, 15(4): 485-459

Central Bank of Sri Lanka 2008 Central Bank Annual Report, Colombo, Sri Lanka.

Department of Agriculture (2011) www. agridept. gov.lk

Hadley G 1969 Elementary Statistics, Holden Day, Inc, Londan.

Khan D, Bashir M, Kassana MJ and Zulfiquar M 2005 "Determining Disrtibutive Marketing Margins of Selected Vegetables in Taingai Tehsil of Charasadda Distruct", Journal of Applied Sciences, 5: $1542-1545$.

Madridakis S, Wheelwright SC and McGee VE 1983 Forecasting Methods and Application. Willey, New York. 245-302

Majumdar PK 2002 Statistics A tool for Social Sciences. Rawat Publications, Satyam Apts., Sector 3, Jain Temple Road, Jawahar Napur, Jaipur, India. $319-385$

Rupasena LP, Kerur NM and Naik AD 2008 Review of price behaviour of rice during pre and post-liberalisation periods, Sri Lanka Journal of Agrarian Studies, 12: 1-18.

Verma A, Kumar S And Singh PM 2002 Marketing and Export of Fresh Vegetables, In Misra, S.N.K. (ed) Agricultural Marketing, India, December, 2002, 15 18-21.

Vidanapathirana RP 2008 Marketing margins of the domestic vegetable trade in Sri Lanka, Sri Lanka Journal of Agrarian Studies, 12 (2): 36 - 60. 